\title{
Studies on the interaction of growth regulators with potassium ions in some physiological processes in bean (Phaseolus vulgaris L.). III. The effect of growth regulators on growth, chlorophyll level and transpiration depending on potassium concentration
}

\author{
JADWIGA STOPIŃSKA
}

\author{
Department of Plant Physiology, Institute of Biology, \\ Copernicus University, Gagarina 9, 87-100 Toruń, Poland \\ (Received: July 24. 1985 . Accepted January 28, 1986)
}

\begin{abstract}
Leaf growth and chlorophyll level in $\mathrm{GA}_{3}$-treated bean, and leaf growth and transpiration intensity in ABA-treated bean plants were studied at two potassium concentrations in the medium ( 1 and $3 \mathrm{mM} \mathrm{KNO}$ ). The plants were grown on Hoagland's solution and growth regulators were applied to the shoot growth apexes. Both $\mathrm{GA}_{3}$ and $\mathrm{K}^{+}$ions were found to stimulate growth of primary leaves and increase their potassium amount. $\mathrm{GA}_{3}$ contrary to $\mathrm{K}^{+}$slightly decreased the potassium content in leaves. Both factors reduced the chlorophyll content but did not affect the total chlorophyll amount in these organs. Interaction between $\mathrm{GA}_{3}$ and $K^{+}$ions was of additive nature. The effect of $\mathrm{ABA}$ and $\mathrm{K}^{+}$ions on growth of both kinds of leaves and on the amount and content of potassium in them were antagonistic. The inhibitory effect of the hormone was stronger at higher potassium concentration in the medium. Either factor reduced transpiration intensity in leaves, however, the inhibitory effect of the growth regulator was stronger at lower potassium concentration. The potassium level modified both the physiological effect of the regulators and the sensitivity of bean particularly to $\mathrm{ABA}$.
\end{abstract}

Key words: Phaseolus, growth requlators, potassium. chlorophyll, transpiration

\section{INTRODUCTION}

It has been pointed out in a number of recent papers that the uptake and transport of mineral substances may be regulated by plant growth regulators (see Pitman 1975. Stopińska 1978. Kaldewey 1984. Stopiń- 
ska 1986a). It has also been demonstrated that mineral substances affect the hormone level in bean plants (Stopińska 1986b). Other reports point out that the effect of growth regulators depends on the supply of mineral substances including potassium. It has been found so far that potassium ions may modify the effect of auxin on wheat coleoptile growth (Haschke and Lüttge 1975), the effect of gibberellin on the growth of stems of sunflower (de la Guardia and Benlloch 1980), internodes in wheat (Chaussat 1968) and in potato seedlings (Wakhloo 1976) as well as the effect of GA on development of leaves (Firsanova and Łukashkina 1973) and initiation of inflorescences (Wakhloo 1976). Potassium also affects the physiological effect of cytokinins (Elliott 1976, Green and Muir 1979) and of abscisic acid (Dörffling and Böttger 1972). However, data on this subject are scarce.

Most of the known effects of gibberellins on plants are connected with juvenility and developmental processes such as for instance increase of the rates of elongation of leaf and hypocotyl tissue and delaying the loss of chlorophyll (Cleland 1969). Some authors claimed however, that $\mathrm{GA}_{3}$ increases leaf growth and simultaneously decreases the chlorophyll content (Szalai 1968). It is known also, that chlorophyll content depends on the potassium supply (Ozbun et al. 1965, Warchołowa 1968) this significantly retarding senescence (Sankhla 1971, cyt. Noodeǹ and Leopold 1978).

Most papers concerning abscisic acid deal with its role in response to chilling or wilting. It was found that in wheat both wilting and ABA injection resulted in smaller leaves owing to the reduced mean cell size and number of stomata (Quarrie and Jones 1977). It is known that higher $\mathrm{ABA}$ levels in leaves cause closure of stomata and reduces transpiration (Beardsell and Cohen 1975, Dörffling et al. 1977). Contrary to ABA, deficiency of potassium enhances the intensity of transpiration (Peaslee and Moss 1968).

Considering the possibility of interaction between growth regulators and potassium ions in the growth of bean leaves (Stopińska 1986a, b), it was decided to estimate the effect of $\mathrm{GA}_{3}$ on growth and chlorophyll level in leaves and the effect of $\mathrm{ABA}$ on leaf growth and transpiration depending on potassium concentration.

\section{MATERIAL AND METHODS}

The material for study was bean (Phaseolus vulgaris L.) var. Saxa aurea. Five-day-old seedlings from a culture grown on perlite at $25^{\circ} \mathrm{C}$ in darkness planted on perforated plates in dishes containing distilled water. On the tenth day after sowing the plants were stripped of assimilating cotyledones and 
transferred to Hoagland's medium diluted in the ratio $1: 2$, with $\mathrm{KNO}_{3}$ in two concentrations, 1 and $3 \mathrm{mM}$. Potassium in lower concentration was substituted by an equivalent amount of $\mathrm{NaNO}_{3}$. The general conditions of further culture were the same as in Part I (Stopińska 1986a).

EXPERIMENT I

After transferring the plants to different media on the tenth day of culture, $0.5 \mu \mathrm{gAA}_{3}$ in $0.05 \%$. Tween 20 was applied to the growth apexes of shoots for two days in succession. The controls were treated with a corresponding amount of $0.05 \%$. Tween. After nine days of culture on different media the surface area of twenty plants and potassium amount were determined in primary leaves. Chlorophyll content $(\mathrm{a}+\mathrm{b})$ was assessed by Mc Kinney's (1941) method, by measuring extinction (A) on a photocolorimeter at 645 and $663 \mathrm{~nm}$. Chlorophyll content $(\mathrm{a}+\mathrm{b})$ was calculated by the formula:

$$
\text { chlorophyll }(\mathrm{a}+\mathrm{b})=8.02 \times \mathrm{A}_{663}+20.20 \times \mathrm{A}_{645} \text {. }
$$

The results were converted to unit surface area and to the entire leaf. The standard error was calculated from three replications.

\section{EXPERIMENT II}

After transferring the plants to different media on the tenth day after sowing, $0.5 \mu \mathrm{g}$ of $\mathrm{ABA}$ in $0.05 \%$. Tween 20 was applied to the growth apexes of shoots for six days in succession. After nine days of culture the surface areas of primary and trifoliate leaves, potassium level in them, transpiration intensity and the aperture of stomata were assessed.

In order to determine the intensity of transpiration, the leaves with petioles were cut off and placed by threes in Erlenmayer flasks containing the same kind of medium that was used in culturing the plants. The flasks were sealed with parafilm against evaporation. The conditions under which transpiration intensity was studied were the same as during plant growth. The flasks with the plants were weighed twice, at the beginning of the experiment and two hours later. Intensity of transpiration was expressed in $\mathrm{g} \cdot \mathrm{cm}^{-2} \cdot \mathrm{h}^{-1}$. The standard error was calculated from three replications.

The aperture of stomata was measured by the collodium film method after Zelitch (1963). On the underside of the basal portions of laminae a thin layer of that preparation was spread. For each variant ten stomatal apertures were measured under $\times 960$ magnification. The mean values were expressed in $\mu \mathrm{m}$, LSD was calculated at $\mathrm{P}=0.05$.

The surface areas of leaves and potassium level in them were estimated in both experiments by the methods described in Part I. In measurements 
of leaf growth LSD was calculated at $\mathrm{P}=0.05$, and in potassium determinations the standard error was taken into account.

Moreover, the effects of both GA and ABA were expressed as percentage of the control values.

\section{RESULTS AND DISCUSSION}

The effect of $\mathrm{GA}_{3}$ on leaf growth and potassium and chlorophyll level in them is presented in Table 1. The stimulation of the surface area of laminae is besides stimulation of elongation. one of the most characteristic effects of gibberellins. $\mathrm{GA}_{3}$ as well as potassium stimulated growth in primary leaves and increased the potassium amount in them at both $\mathrm{K}^{+}$ concentrations in the medium (Table 1). $\mathrm{GA}_{3}$, however, contrary to potassium slightly decreased the $\mathrm{K}^{+}$content in leaves in both nutrient variants. This influence probably resulted from the effect of dilution. It has been found in several studies on intact plants, mainly leaves and shoots, that as growth was stimulated, $\mathrm{K}^{+}$content in these organs increased (Stojanov 1974, Saimbhi et al. 1975). The increase in potassium amount in the leaves caused by $\mathrm{GA}_{3}$, which $\mathrm{I}$ found in my experiments, probably resulted from an enhancement of the uptake and transport of this ion, as also found by other authors (Garcia and Guardiola 1981, Benlloch et al. 1983, Starck et al. 1984). The data presented above show that the effect of $\mathrm{GA}_{3}$ and potassium on growth and on $\mathrm{K}^{+}$amount in bean leaves are similar and additive. There was no difference in the effect of $\mathrm{GA}_{3}$ relatively to control depending on the potassium level in the medium. This may be due to the lack of significant differences in $\mathrm{K}^{+}$content in leaves of plants cultured at both concentrations of that ion in the medium (Table 1). This fact is inconsistent with the reports of Wakhloo (1975) and Starck et al. (1980) that plants containing potassium in low concentration show higher susceptibility to gibberellin.

$\mathrm{GA}_{3}$ did not significantly influence the chlorophyll $(\mathrm{a}+\mathrm{b})$ content in the leaves, irrespective of the potassium level in the medium (Table 1). The effect of $\mathrm{GA}_{3}$ appeared in the increased surface area of the leaves and their lighter colour due to dilution. Szalai (1968) reported similar observations on bean. A similar effect was observed at increased potassium concentration in the medium. On low-potassium medium the leaves were darker; this was probably due to initial changes, observed as untypical of drastic potassium deficiency. These characteristics probably resulted from sufficient transport of potassium from other organs to the leaves. These data are in line with the results of Ozbun et al (1965), who observed similar changes in chlorophyll content in bean at potassium deficiency of short duration. 
Table 1

Influence of gibberellic acid on primary bean leaves growth and on chlorophyll and potassium level in relation to $\mathrm{K}^{+}$concentration in the medium

\begin{tabular}{|c|c|c|c|c|c|c|c|c|c|c|}
\hline \multirow{3}{*}{$\begin{array}{l}\text { Kind of } \\
\text { variant }\end{array}$} & \multicolumn{5}{|c|}{$1 \mathrm{mM} \mathrm{K}^{+}$} & \multicolumn{5}{|c|}{$3 \mathrm{mM} \mathrm{K}^{+}$} \\
\hline & \multirow{2}{*}{$\begin{array}{c}\text { surface } \\
\text { area of } \\
\text { leaves, } \\
\mathrm{cm}^{2}\end{array}$} & \multicolumn{2}{|c|}{$\begin{array}{l}\text { chlorophyll } \\
(\mathrm{a}+\mathrm{b})\end{array}$} & \multicolumn{2}{|c|}{ potassium } & \multirow{2}{*}{$\begin{array}{c}\text { surface } \\
\text { area of } \\
\text { leaves, } \\
\mathrm{cm}^{2}\end{array}$} & \multicolumn{2}{|c|}{$\begin{array}{c}\text { chlorophyll } \\
(\mathrm{a}+\mathrm{b})\end{array}$} & \multicolumn{2}{|c|}{ potassium } \\
\hline & & $\begin{array}{l}\text { content, } \\
\mathrm{mg} \cdot \mathrm{dm}^{-2}\end{array}$ & $\begin{array}{c}\text { amount. } \\
\text { mg per } \\
\text { leaf }\end{array}$ & $\begin{array}{l}\text { content } \\
\mathrm{mg} \cdot \mathrm{g}^{-1} \\
\mathrm{~d} . \mathrm{w} .\end{array}$ & $\begin{array}{l}\text { mg per } \\
\text { leaf }\end{array}$ & & $\begin{array}{l}\text { content, } \\
\mathrm{mg} \cdot \mathrm{dm}^{-2}\end{array}$ & $\begin{array}{c}\text { amount, } \\
\text { mg per } \\
\text { leaf }\end{array}$ & $\begin{array}{l}\text { content, } \\
\mathrm{mg} \cdot \mathrm{g}^{-1} \\
\text { d.w. }\end{array}$ & $\begin{array}{c}\text { amount, } \\
\text { mg per } \\
\text { leaf }\end{array}$ \\
\hline $\begin{array}{l}\text { Control } \\
\mathrm{GA}_{3}\end{array}$ & $\begin{array}{l}27.5 \\
33.0^{\mathrm{b}}\end{array}$ & $\begin{array}{r}2.65 \\
\pm 0.10 \\
2.12 \\
\pm 0.01\end{array}$ & $\begin{array}{r}0.73 \\
\pm 0.03 \\
0.70 \\
\pm 0.01\end{array}$ & 46 & $\begin{array}{r}2.6 \\
\pm 0.1 \\
3.0 \\
\pm 0.1\end{array}$ & $\begin{array}{l}31.4^{\mathrm{a}} \\
39.5^{\mathrm{ab}}\end{array}$ & $\begin{array}{r}2.32 \\
\pm 0.01 \\
1.70 \\
\pm 0.17\end{array}$ & $\begin{array}{r}0.73 \\
\pm 0.03 \\
0.67 \\
\pm 0.03\end{array}$ & $\begin{array}{l}49 \\
47\end{array}$ & $\begin{array}{r}2.9 \\
\pm 0.1 \\
3.2 \\
\pm 0.1\end{array}$ \\
\hline $\begin{array}{l}\% \text { In rela- } \\
\text { tion to } \\
\text { control }\end{array}$ & 120.0 & 80.0 & 95.5 & 91.3 & 115.4 & 125.8 & 73.3 & 91.8 & 95.9 & 110.3 \\
\hline
\end{tabular}

Abbreviations: ${ }^{a}$ - significant differences at $\mathrm{P}=0.05$ for $\mathrm{K}^{+}$concentrations, ${ }^{\mathrm{b}}$ - significant differences at $\mathrm{P}=0.05$ for treatments, \pm - standard error. 
With severe and long-lasting $\mathrm{K}^{+}$deficiency there was generally a drop in chlorophyll content (Ozbun et al. 1965, Warchołowa 1968). This effect probably resulted from the role of $\mathrm{K}^{+}$in the syntheses of porophyrin (Bush 1969), necessary for the synthesis of chlorophyll.

The effect of ABA on leaf growth, potassium level and intensity of transpiration is presented in Tables 2 and 3 and Fig. 1. The effect of ABA
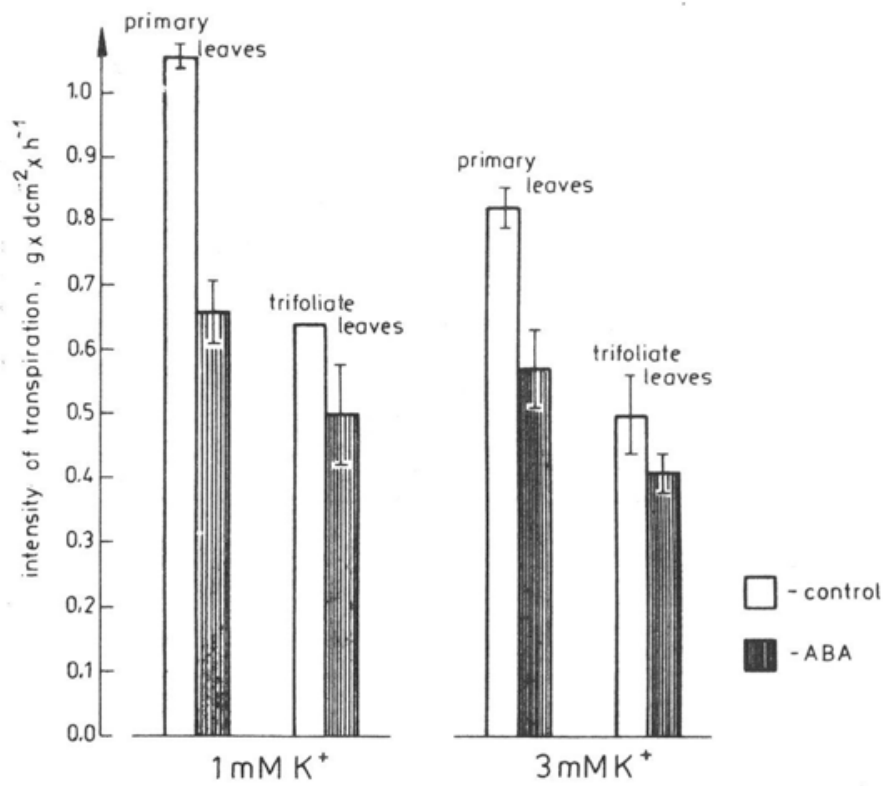

Fig. 1. Transpiration intensity of bean leaves depending on $\mathrm{ABA}$ application and $\mathrm{K}^{+}$concentration in the medium. Vertical lines - standard errors

on leaf growth in bean at different potassium concentration is shown in Table 2. Unlike $\mathrm{GA}_{3}, \mathrm{ABA}$ inhibited growth of both kinds of leaves and reduced the content and amount of $\mathrm{K}^{+}$in them, irrespective of the potassium concentration in the medium. The leaf growth-inhibiting effect of $\mathrm{ABA}$ is a commonly known fact and may be due, among other things, to the reduction of cell size and the number of stomata (Quarrie and Jones 1977). There has been lately an increasing number of reports on the physiological effects of this regulator leading to a reduction in the content of $\mathrm{K}^{+}$ (Dörffling et al. 1973, Dekock et al. 1978). Some researchers report inhibition of $\mathrm{K}^{+}$uptake and transport in ABA-treated intact plants of barley (Pitman and Wellfare 1978), sunflower (Erlandson et al. 1978) and bean (Karmoker and Steveninck 1979). According to my results, the actions of $\mathrm{ABA}$ and potassium were antagonistic. The inhibiting effect to the hormone was enhanced by a higher level of potassium in the leaves, which is in line with the results of other authors (Dörffling and Böttger 1972). This fact 


\section{Table 2}

Influence of abscisic acid on growth and potassium level in primary and trifoliate bean leaves in relation to $\mathrm{K}^{+}$concentration in the medium

\begin{tabular}{|c|c|c|c|c|c|c|c|c|c|c|c|c|}
\hline \multirow{4}{*}{$\begin{array}{l}\text { Kind of } \\
\text { variant }\end{array}$} & \multicolumn{6}{|c|}{$1 \mathrm{mM} \mathrm{K}^{+}$} & \multicolumn{6}{|c|}{$3 \mathrm{mM} \mathrm{K}^{+}$} \\
\hline & \multirow{2}{*}{\multicolumn{2}{|c|}{$\begin{array}{l}\text { surface area of } \\
\text { leaves, } \mathrm{cm}^{2}\end{array}$}} & \multicolumn{4}{|c|}{ potassium } & \multirow{2}{*}{\multicolumn{2}{|c|}{$\begin{array}{l}\text { surface area of } \\
\text { leaves, } \mathrm{cm}^{2}\end{array}$}} & \multicolumn{4}{|c|}{ potassium } \\
\hline & & & \multicolumn{2}{|c|}{$\begin{array}{c}\text { content, } \\
\mathrm{mg} \cdot \mathrm{g}^{-1} \mathrm{~d} . \mathrm{w}\end{array}$} & \multicolumn{2}{|c|}{$\begin{array}{l}\text { amount, } \\
\text { mg per leaf }\end{array}$} & & & \multicolumn{2}{|c|}{$\begin{array}{c}\text { content, } \\
\mathrm{mg} \cdot \mathrm{g}^{-1} \text { d.w. }\end{array}$} & \multicolumn{2}{|c|}{$\begin{array}{l}\text { amount, } \\
\text { mg per leaf }\end{array}$} \\
\hline & prim. & trif. & prim. & trif. & prim. & trif. & prim. & trif. & prim. & trif. & prim. & trif. \\
\hline Control & 16.9 & 18.4 & 42 & 54 & $\begin{array}{r}1.3 \\
\end{array}$ & 2.4 & $22.9^{\mathrm{a}}$ & $30.9^{\mathrm{a}}$ & 50 & 55 & $\begin{array}{r}1.8 \\
+01\end{array}$ & 3.0 \\
\hline $\mathrm{ABA}$ & $15.4^{\mathrm{b}}$ & $16.6^{b}$ & 41 & 51 & $\begin{array}{r}1.2 \\
\pm 0.1\end{array}$ & $\begin{array}{r}2.1 \\
\pm 0.2\end{array}$ & $17.9^{\mathrm{ab}}$ & $22.1^{\mathrm{ab}}$ & 46 & 51 & $\begin{array}{r}1.4 \\
\pm 0.1\end{array}$ & $\begin{array}{r}2.4 \\
\pm 0.2\end{array}$ \\
\hline $\begin{array}{l}\% \text { In rela- } \\
\text { tion to } \\
\text { control }\end{array}$ & 8.9 & 9.8 & 2.4 & 5.6 & 7.7 & 12.5 & 21.8 & 28.5 & 8.0 & 7.3 & 22.2 & 20.0 \\
\hline
\end{tabular}

Prim. - primary, trif - trioliate. Other abbreviations - as in Table 1. 
indicates that plants with higher potassium level show higher sensitivity to ABA. The response of either kind of leaves showed no significant differences.

The results of investigations of transpiration presented in Fig. 1 demonstrate that the reduction of the potassium concentration from 3 to $1 \mathrm{mM}$ enhanced transpiration intensity in both kinds of leaves to a similar extent. This is in accordance with the opinions of other authors (Peaslee and Moss 1968) that $\mathrm{K}^{+}$deficiency enhances the intensity of transpiration, and is reflected in the withered appearance of the leaves. In general, plants containing less potassium in the leaves showed a higher intensity of transpiration. Adequate $\mathrm{K}^{+}$supply is necessary for the plant to utilize water economically, this involving a decrease of the coefficient of transpiration. The data concerning the degree of opening of stomata (Table 3) confirm

Table 3

Influence of abscisic acid on stomatal aperture of bean lealves in relation to $\mathrm{K}^{+}$concentration in the medium

\begin{tabular}{|l|c|c|c|c|}
\hline \multirow{2}{*}{$\begin{array}{l}\text { Kind of } \\
\text { variant }\end{array}$} & \multicolumn{3}{|c|}{$1 \mathrm{mM} \mathrm{K}^{+}$} & \multicolumn{2}{c|}{$3 \mathrm{mM} \mathrm{K}^{+}$} \\
\cline { 2 - 5 } & $\begin{array}{c}\text { stomatal aperture, } \mu \mathrm{m} \\
\text { primary } \\
\text { leaves }\end{array}$ & $\begin{array}{c}\text { trifoliate } \\
\text { leaves }\end{array}$ & $\begin{array}{c}\text { primary } \\
\text { leaves }\end{array}$ & $\begin{array}{c}\text { trifoliate } \\
\text { leaves }\end{array}$ \\
\hline Control & 11.0 & 9.4 & $9.9^{\mathrm{a}}$ & $8.4^{\mathrm{a}}$ \\
$\mathrm{ABA}$ & $7.6^{\mathrm{b}}$ & $8.5^{\mathrm{b}}$ & $7.5^{\mathrm{b}}$ & $7.8^{\mathrm{ab}}$ \\
\hline O In rela- & & & & \\
tion to & & & & \\
control & 30.9 & 11.7 & 24.3 & 7.2 \\
\hline
\end{tabular}

Abbreviations a as in Table 1

the conclusions concerning transpiration intensity. Considering the fact that the opening of stomata is linked with high potassium content in the guard cells (Fischer and Hsiao 1968), those data seem to be contradictory. However, according to Peaslee and Moss (1968), the stress caused by $\mathrm{K}^{+}$ deficiency in the leaf at first promotes potassium migration from the guard cells to more active cells of the mesophyll. As $k^{+}$deficiency becomes more and more pronounced, all mesophyll cells except the guard cells would become deficient. It seems likely that this mechanism was in operation in the present case.

ABA like higher $\mathrm{K}^{+}$concentration inhibited transpiration intensity and reduced the stomatal aperture (Fig. 1, Table 3). There have been a number of reports indicating that $\mathrm{ABA}$ reduces accumulation of $\mathrm{K}^{+}$ions in guard cells, this leading to a rapid loss of turgor and closure of stomata (Mansfield and Jones 1971). The present data are in line with reports 
indicating that a higher ABA level in leaves closure of stomata and reduces transpiration (Beardsell and Cohen 1975. Dörffing et al. 1977). The present data indicate that, $\mathrm{K}$ concentration plays a significant role in the inhibition of transpiration by ABA. The effect of this hormone was stronger at $\mathrm{K}^{+}$level $1 \mathrm{mM}$ than $3 \mathrm{mM}$, and in primary leaves, characterized by higher transpiration intensity and lower $\mathrm{K}^{+}$content and amount, than trifoliate leaves. This however, may have been due to a different IAA/ABA ratio, as pointed out by Snaith and Mansfield (1982). This difference may be a result of a lower ABA level in the primary leaves at $1 \mathrm{mM} \mathrm{K}^{+}$ concentration in the medium which was demonstrated in earlier experiments (Stopińska 1986b) and, consequently, of their greater sensitivity to the exogenous regulator. The sensitivity of the guard cells to ABA has been found to be reduced by prolonged stress or an increasing level of $\mathrm{ABA}$ (Kriedemann et al. 1972. Raschke 1975, Dörffling et al. 1977). Considering, however, the specific physiology of guard cells, it should be noted that in general the total ABA level in leaves cannot be regarded as an indicator of the condition of the stomata. Probably only part of the total ABA in the leaf is involved in the stomatal movement (Walton et al. 1977). Likewise, the total $\mathrm{K}^{+}$content in the whole leaf cannot be the only measure of the degree of stomatal opening.

The specific interaction of growth regulators with potassium ions as exemplified in certain physiological processes in bean, throws some light on the mechanism of action of both these factors which is still insufficiently understood. The present data as well as reports from literature indicate that growth regulators affect the potassium level in plants by controlling the uptake and transport of $\mathrm{K}^{+}$ions which, in turn, influence the plant's growth and development. On the other hand, the effect of regulators and the plant's sensitivity to them depend on potassium supply. It seems that a number of physiological processes, often unspecifically regulated by hormones, may be associated with the effect of mineral substances including potassium. It is also possible that physiological effect of growth regulators is modified by potassium via the influence on the activity, synthesis and transport of hormones in plants. Hence in studies on the interaction between potassium ions and growth regulators one of the principial difficulties is to determine which effect is primary and which secondary. This interaction, however, may have be of feed-back nature.

REFERENCES

Beardsell M. F., Cohen D., 1975. Relationships between leaf water status, abscisic acid levels and stomatal resistance in maize and sorghum. Plant Physiol. 56: 207-212. 
Benlloch M., Fournier J. M., de la Guardia M. D., 1983. Effect of gibberellic acid on $\mathrm{K}^{+} / \mathrm{Rb}^{+}$uptake and transport in sunflower roots. Physiol. Plant. 57: 79-84.

Bush L. P., 1969. Influence of certain cations on activity of succinyl CoA synthetase from tobacco. Plant Physiol. 44: 347-350.

Chaussat R., 1968. Action particulière du potassium sur la croissance et la morphologie des plantules ètioleès de blè. Ann. Physiol. Veg. 10: 5-16.

Cleland R. E., 1969. Gibberellins. In: The Physiology of Plant Growth and Development. M. B. Wilkins (ed.). Mc Grow-Hill, London. pp. 47-81.

Dekock P. C.. Vaughan D. Hall A. 1978. Effects of abscisic acid and benzyladenine on the inorganic and organic composition of the duckweed. Lemma sibha L. Phytology 81 : 505-511

Dörffling K., Bellandi D. M., Böttger M., Lückel H., Menzer U., 1973. Abscisic acid: properties of transport and effect on distribution of potassium and phosphorus. $\operatorname{Pr}$. Inst. Sadown. Skierniewice E. 3: 259-272.

Dörffling K., Böttger M., 1972. Steigerung der Keimungs-hemmenden Wirkung von Abscisinsäure auf Lactuca-Früchte durch Saccharose and Glucose. Planta 103: 340-347.

Dörffling K., Streich J., Kruse W., Muxfeldt B., 1977. Abscisic acid and the after-effect of water stress on stomatal opening potential. Zeitsch. Pflanzenphysiol. 81: 43-56.

Elliott D. C., 1976. Cytokinin action in enzyme induction is membrane-related phenomenon. Abs. 9th Int. Conf. on Plant Growth Substances. Lausanne. pp. 86-87.

Erlandson G., Petterson S., Swensson S. B., 1978. Rapid effects of abscisic acid on ion uptake in sunflower roots. Physiol. Plant. 43: 380-384.

Firsanova G. N., Łukashkina T. A., 1973. Izmeneniya anatomomorfologicheskoy struktury kormovykh bobov $\mathrm{v}$ zavisimosti ot sposoba obrabotki gibberellinom i urovnia mineralnogo potaniya. Ref. Zhur. 1975, 6G-271: 35 .

Fischer R. A., Hsiao T. G., 1968. Stomatal opening in isolated epidermal strips of Vicia faba. II. Response to $\mathrm{KCl}$ concentration and the role of potassium absorption. Plant Physiol. 43: 1953-1958.

Garcia A. L., Guardiola J. L., 1981. Effect of gibberellic acid on ion uptake selectivity in pea seedlings. Planta 153: 494-496.

Green J F. Muir R. M.. 1979. An analysis of the role of potassium in the growth effects of cytokinin, light and abscisic acid on cotyledon expansion. Physiol. Plant. 46: 19-24.

De la Guardia M. D. Benlloch M., 1980. Effects of potassium and gibberellic acid on stem growth of whole sunflower plants. Physiol. Plant. 49: 443-448

Haschke H. P. Lüttge U.. 1975. Interaction between IAA, potassium and malate accumulation and growth in Avena coleoptile segments. Zeitsch. Pflanzenphysiol. 76: 450-455.

Kaldewey H., 1984. Transport and other modes of movement of hormones (mainly auxins). In: Hormonal Regulation of Development. II. T. K. Scott (ed.). Springer-Verlag, Berlin-Heidelberg-New York-Tokyo. pp. 80-148.

Karmoker J. L., Van Steveninck R. F. M., 1979. The effect of abscisic acid on the uptake and distribution of ions in intact seedlings of Phaseolus vulqaris cv. Redland Pioneer. Physiol. Plant. 45: 453-459.

Mc Kinney G., 1941. Absorption of light by chlorophyll solutions. J. Biol. Chem. 140: 315-322.

Kriedemann P. E., Loveys B. R., Fuller G. L., Leopold A. C., 1972. Abscisic acid and stomatal regulation. Plant Physiol. 49: 842-847.

Mansfield T. A. Jones R. J., 1971. Effects of abscisic acid on potassium uptake and starch content of stomatal guard cells. Planta 101: 147-158.

Noodeń L. D., Leopold A. C., 1978. Phytohormones and the endogenous regulation of senescence and abscission. In: Phytohormones and Related Compounds. A Compre- 
hensive Treatise II D. S. Letham. P. B. Godwin. T. J. V. Higgins (eds.). Elsevier/North-Holand Biomed. Press. Amsterdam-Oxford-New York. pp. 329-369.

Ozbun J. L. Volk R. J.. Jackson W. A., 1965. Effect of potassium deficiency on photosynthesis. respiration and utilization of photosynthetic reductant by immature bean leates Crop Sci 5:69-75.

Peaslee D. E., Moss D. N., 1968. Stomatal conductivities in K-deficient leaves of maize (Zea mays L.). Crop Sci. 8: 427-430.

Pitman M G. 1975. Whole plants. In: Ion Transport in Plant Cells and Tissues. D. A. Baker, J. L. Hall (eds.). North-Holland/American Elsevier. Amsterdam-Oxford-New York. pp. 301-305.

Pitman M. G., Wellfare D., 1978. Inhibition of ion transport in excised barley roots by abscisic acid relation to water permeability of the roots. J. Exp. Bot. 29: 1125-1238.

Quarrie S. A., Jones H. G., 1977. Effect of abscisic acid and water stress on development and morphology of wheat. J. Exp. Bot. 28: 192-203.

Raschke K.. 1975. Stomatal action. Ann. Rev. Plant Physiol. 26: 309-340.

Saimbhi M. S., Arora S. K., Chhibba I. M., 1975. Influence of seed treatment with 2-chloroethylphosphonic acid, gibberellic acid, ascorbic acid, and simazine on growth and nutrient composition of pea (Pisum sativum L.) seedlings. Plant and Soil 43: 697-699.

Snaith P. J., Mansfield T. A., 1982. Control of the $\mathrm{CO}_{2}$ response of stomata by indolyl-3-acetic acid and abscisic acid. J. Exp. Bot. 33: 360-365.

Starck Z.. Cholui B.. Szczepanska B.. 1980. Photosynthesis and photosynthates distribution in potasium-deficient radish plants treated with indolyl-3-acetic acid or gibberellic acid. Photosynthetica 14: 497-505.

Starck Z. Szczepańska B. Chołuj B., Ślaski J.. 1984. Effect of $\mathrm{GA}_{3}$ on the distribution of assimilates and ion absorption in potassium-deficient radish plants. Proc. II. Intern. Symp. Plant Nutrition. IV. Publ. House of Centr. Cooperative Unit, Sofia. pp. 335-338.

Stojanov I., 1974. Vlijaniye gibberelovoj kisloty na soderzhaniye mineralnykh veshchestv $\mathrm{v}$ listjakh kukuruzhy $\mathrm{v}$ zavisimosti ot uslovij mineralnogo pitaniya. Fizyol. Rast. 1: $31-45$

Stopinthat I I978 The interaction of phytohormones and potassium ions in plant physiologecal processes Post. Natuk Roln. 6: 73-92

Stopinska J., 1986a. Studies on the interaction of growth regulators with potassium ions in some physiological processes in bean (Phaseolus vulqaris L.). I. The effect of growth regulators on the growth of leaves and on the potassium level in leaves and roots. Actat Soc Bot Pol 55: 199-207

Stopinsha J., 1986b. Studies on the interaction of growth regulators with potassium ions in some physiological processes in bean (Phaseolus vulqaris L.). II. The effect of potassium on growth of bean leaves and on their potassium and hormone level. Acta Soc. Bot. Pol $55.209-225$

S/alai I. 1968. Gibberellic acid and chlorophyll content of leaves of Phaseolus vulqaris L. Planta 83: 161-165

Wakhloo J. L. 1975. Studies on the growth, flowering and production of female sterile flowers as affected by different levels of foliar potassium in Solanum sisymbrifolium Lam. II. Interaction between foliar potassium and applied gibberellic acid and 6-furfurylaminopurine. J. Exp. Bot. 26: 433-440.

Wakhloo J. L., 1976. Changes in endogenous gibberellin-like substances in the vegetative shoot and inflorescences in Solanum sisymbrifolium Lam. in relation to potassium content of the plant. J. Exp. Bot. 27: 794-800.

Walton D. C., Wellner R., Horgan R., 1977. Synthesis of tritiated ABA of high specific activity. Phytochemistry 16: 1059-1061. 
Warcholowa M., 1968. The influence of potassium on the metabolism of sugar beet infected by virus yellows. I. Water balance and the intake of some nutrient elements. Pam Puł 33: 91-142.

Zelitch I., 1963. The control and mechanism of stomatal movement. In: Stomata and Water Relations in Plants. I. Zelitch (ed.). Connecticut Agr. Exp. Sta. Bull. 664: 18-42.

Studia nad wspóldzialeniem requlatorów wzrostu z jonami potasowymi $w$ niektórych procesach fizjologicznych $u$ fasoli (Phaseolus vulgaris L.). III. Wplyw regulatorów wzrostu na wzrost, poziom chlorofilu i transpirację $w$ zależności od stężenia potasu

\section{Streszczenie}

Badano wzrost liści fasoli $\mathrm{i}$ poziom $\mathrm{w}$ nich chlorofilu pod wpływem $\mathrm{GA}_{3}$ oraz wzrost liści i intensywność transpiracji pod wpływem ABA przy różnym stężeniu potasu w pożywce (1 i $3 \mathrm{mM} \mathrm{KNO}_{3}$ ). Rośliny rosły na pożywce wodnej Hoaglanda, a regulatory podawano na wierzchołki wzrostu pędów. Stwierdzono, że $\mathrm{GA}_{3} \mathrm{i}$ jony $\mathrm{K}^{+}$stymułowały wzrost juwenilnych liści fasoli zwiększając $w$ nich ilość potasu. $\mathrm{GA}_{3}$ w przeciwieństwie do potasu nieco, obniżał zawartość $\mathrm{K}^{+}$w liściach. Obydwa te czynniki obniżały zawartość chlorofilu, lecz nie wywarły istotnego wpływu na ogólną jego ilość w tych organach. Interakcja $\mathrm{GA}_{3} \mathrm{z} \mathrm{K}^{+}$ miała charakter addytywny.

ABA $\mathrm{i}$ jony $\mathrm{K}^{+}$oddziaływały na wzrost obu rodzajów liści, tj. juwenilnych $\mathrm{i}$ trójdzielnych oraz na ogólną w nich ilość i zawartość potasu w sposób antagonistyczny; hamujący wplyw hormonu byl silniejszy przy większym stężeniu potasu w pożywce. Obydwa czynniki zmniejszały intensywność transpiracji liści, przy czym hamujący efekt hormonu był silniejszy przy mniejszym stężeniu potasu w pożywce. Stężenie potasu w środowisku modyfikowało zarówno efekt fizjologiczny regulatorów jak i wrażliwość fasoli, szczególnie na ABA. 